\title{
Local Rural Gastronomic Traditional Tourism. A Strategy for Local and Regional Development, at the South of the State of México
}

\author{
By Jesus Gaston Gutierrez Cedillo* \\ Jose Isabel Juan Perez ${ }^{\dagger}$ \\ Elsa Mireya Rosales Estrada
}

\begin{abstract}
During 2010, we started the promotion of communitarian projects at Progreso Hidalg village, located in the Central Mexican Subtropical Highlands. Then, during 2013, we began the management and installation of two communitarian projects: one agro-industrial and the other, eco-touristic, which are both operating nowadays. The transaction procedures were made on behalf of Women in Agrarian Sector Program (PROMUSAG) and financed by the Agrarian Reform Ministry of Mexico. The method applied for environmental, economic, and social characterization consisted of the design and application of a questionnaire; interviews with families; direct systematic observation on field, observing natural environments and cultivated fields, geo-referenced sites through a Differential Global Positioning System, as well as the making of automatized cartography. As a diagnosis, Natural and Social Sustainable Resources Management Strategies were applied in order to analyze them from a Logic Frame Approach and participatory diagnosis. We are currently working on the design and transaction procedures of an Agro Alimentary Located System (SIAL), at a regional scale, based on a Local Rural Gastronomic Traditional Tourism project at a local scale. In order to encourage the management of the project, feasibility, profitability and viability analysis as well as a participatory prospective were carried out to end up in a Multi-scale Strategy for the development of a regional SIAL, based on local, regional tourism and gastronomic qualities. The research gets theoretical support over the SIAL approach and the Rural and Gastronomic Tourism. The SIAL approach highlights the importance of mesh and network functioning of small agroalimentarian enterprises at Progreso Hidalgo, along with other formal and informal local organization units, at territorial scale.
\end{abstract}

${ }^{*}$ Professor, Autonomy University of Estado, Mexico.

${ }^{\dagger}$ Professor, Autonomy University of Estado, Mexico.

"Professor, Autonomy University of Estado, Mexico. 


\section{Introduction}

A form of significant intervention of societies towards their local environment is farming activity. An approach of the agricultural methods and techniques is rural tourism. Our purpose in this work is to strengthen the idea that traditional gastronomic tourism can contribute to improving the sustainability of agricultural systems, both in its environmental components (natural resources) and social ones (mainly rural farmers), in order to activate a system located at a regional level.

The rural tourism incorporates to agriculture concepts of stability, resilience and adaptability, in addition to productivity, efficiency and effectiveness in the production. The purpose is to improve the well-being, quality of life and equity among farmers (Toledo, 2000). With the design and management of a SIAL it is possible to improve the rural economy, so this project can be a generator that will help to raise employment and quality of the life of the local inhabitants in Progreso, Hidalgo, a Municipality of Villa Guerrero in the State of Mexico.

\section{Background}

This research is supported by the SIAL theoretical approach (RequierDesjardins, 2002; Muchnik, 2004; Boucher, 2003 and 2006; Monroy, et al., 2007), rural tourism (Cuesta, 1996; Bertoncello, 2002; Barrera, 2006; Bringas, 2006) and gastronomic tourism (Muchnik and Sautier, 1998; Blanco, 2006). Since the approach SIAL underlines the importance of the operation in networks of small agro-businesses companies in Progreso, Hidalgo and its relations with other forms of local organization, either formal or informal, at a territorial level.

It is useful to analyze the emergence and strengthening of businesses and production of endogenous origin, depending on their location, in order to deepen the understanding of its structure, functioning and dynamics, as well as the identification of the specific resources and assets to develop, jointly with the actors involved, activation schemes to develop an effective on the sustainable development of the territory, in its economic, social, and environmental dimensions.

The Localized Agro Alimentary Systems, usually called SIAL (Sistema Agro Alimentario Localizado), is a process of territorial construction which detects and activates local resources that exist in a rural region, to achieve its economic development. Therefore it is important to investigate the interactions between the local development and the territorial dynamics, which leads to raise the concept of SIAL that is directly related to the Rural Agroindustry, usually called AIR (Agro Industria Rural), a local production system where territory becomes a major historically and socially constructed actor. 


\section{Methodology}

The methodology included: first, an observation process and then a diagnostic second phase, taking into account the environmental, socio-cultural and socio-economic approaches to carry out a complete geographic diagnosis, at local level, in order to identify the potential and limitations for the management of a project of Rural and Traditional Gastronomic Tourism (Turismo Gastronómico Tradicional Rural) (TGTR). A complete geographic diagnosis mean by Logic Framework Approach (Camacho, 2001), was also carried out, including the municipalities of Ixtapan de la Sal, Tonatico, Villa Guerrero and Zumpahuacán, in order to identify the potential and limitations for the development of a SIAL (Figure 1).

Figure 1. Location of Progreso Hidalgo, a Municipality of Villa Guerrero, State of Mexico
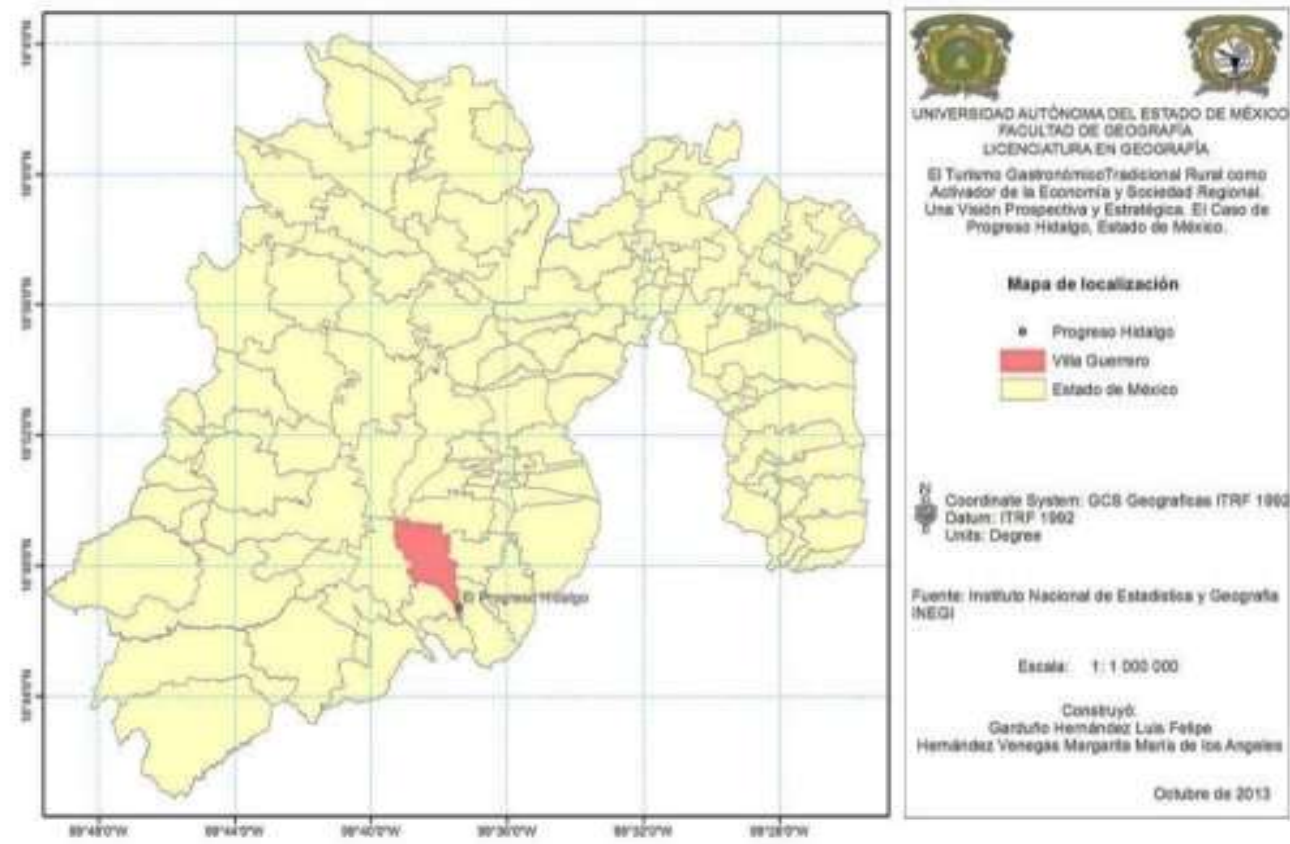

Source: It was designed with the cartography of IGECEM (2010)

The region study is located at south of the State of Mexico, and it belongs to the VI Region VI of Ixtapan de la Sal, which is bordered to the North with the regions of Valle de Bravo and Toluca, on the East by the State of Morelos, the South with the State of Guerrero and the West with the Tejupilco Region (Figure 2). 
Figure 2. Location of the Region in the Context of the State and the Country of Mexico

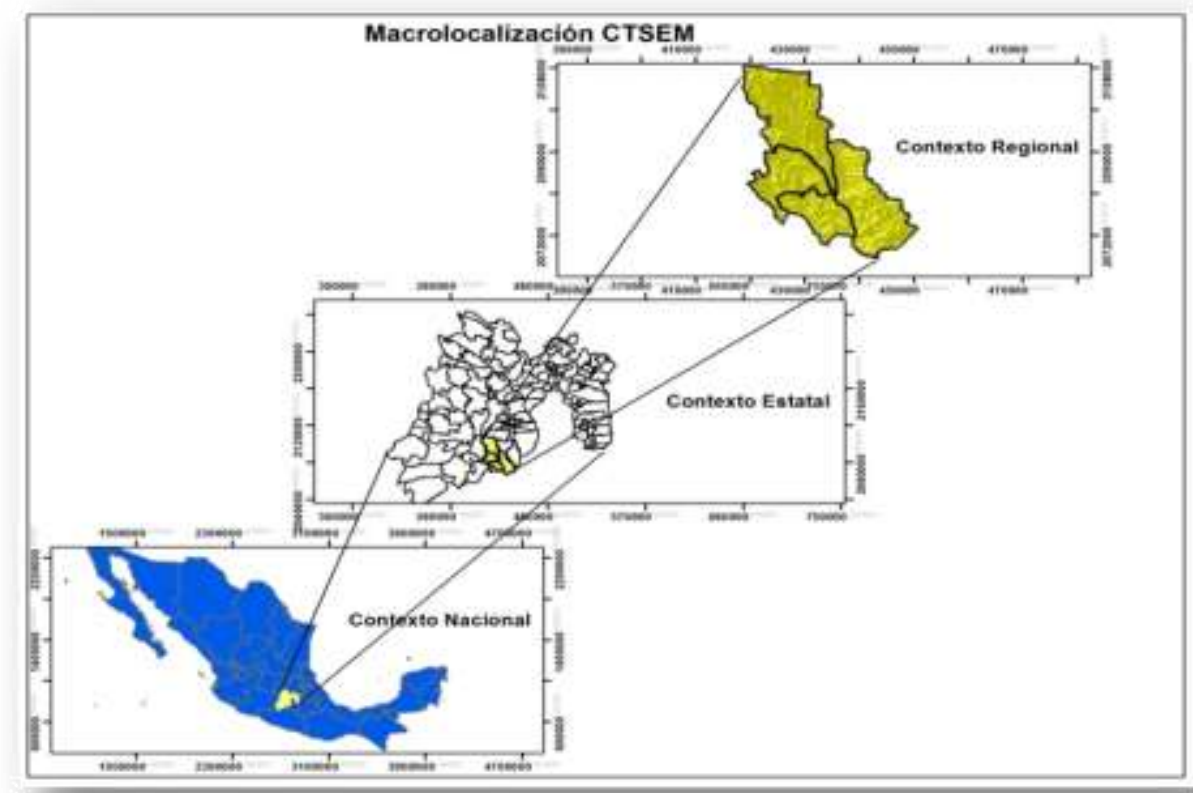

Source: It was designed with the cartography of IGECEM (2010)

The third phase was of prospecting. The expected scenarios were designed for the community and the region, according to a SIAL, at a regional level, and based on TGTR at a local level. Then the tendency scenario, the strategic scenario or objective image were made for both the community and the region. Finally, an analysis of profitability, viability and feasibility of the project was carried out. The analysis was conducted on the basis of the methodology NAFIN-OEA (1990) for the development and assessment of investment projects. We filled up the PROMUSAG form, for transaction procedures.

During the proposal stage, at the regional level, the identification and characterization of tourist attractions, restaurants and crafts was done, considering the ones that currently exist in the seven municipalities (four as destiny and three as pass way) that we have defined as members of the Tourist Circuit of the South of the State of Mexico, to include them in the study. During the management phase, some strategies were implemented to promote the development of new business opportunities, in the main local economic sectors, promoting projects in emerging sectors, based on culinary tourism and the management of a SIAL, at a regional level.

\section{Location}

The place, where the projects were set up, is located in Progreso Hidalgo. It belongs to the Agricultural Unit of Villa Guerrero, found in the strawberry region. 
The kind of climate is $\mathrm{A}(\mathrm{C}) \mathrm{wg}$. In accordance with the Classification System of Köeppen Climate, this type of climate is tropical, with a transition between the warm climate and the cold one, high temperatures during the spring and summer, which is a characteristic of the ecological transition zone, located precisely in the southeast of the State of Mexico.

The temperature of the warmest month is present before the summer solstice. The annual average temperature in the north of the region is of $18^{\circ}$ and in the south is $20^{\circ}$. During the summer season there is a period called "heatwave", which occurs between July and August (Gobierno del Estado de México, 1995:28). Humidity has an unequal distribution during the year, clearly dividing the rainy and dry seasons. The average of the annual rainfall is variable, between 300 and $1800 \mathrm{~mm}$ (most often between 600 and $1200 \mathrm{~mm}$ ) (Garcia, 1986).

\section{Results}

Table 1 and Table 2 show the general data of the projects, which have been promoted and installed in Progreso, Hidalgo, as well as the objectives, rationale and goals. The two projects that were installed in 2013 are the projects of "Strawberries and their derivatives" and "Ecological Tourism with Equestrian Tours"; the "Local and Rural Traditional Gastronomy Tourism" is at the stage of promotion, once the design stage is over.

Table 1. General Data of the Projects already Promoted and Installed in Progreso, Hidalgo

\begin{tabular}{|l|l|l|l|}
\hline Main & Strawberries and \\
Characteristics & $\begin{array}{l}\text { Ecological Tourism } \\
\text { with Equestrian Tours }\end{array}$ & $\begin{array}{l}\text { Local and Rural } \\
\text { Traditional } \\
\text { Gastronomy } \\
\text { Tourism }\end{array}$ \\
\hline Kind of Project & Agro-rural industry & Rural Tourism & Rural Tourism \\
\hline Final product & $\begin{array}{l}\text { Non-perishable food } \\
\text { products derived from } \\
\text { Strawberries }\end{array}$ & Rural Equestrian Tours & Cabins-Restaurants \\
\hline Members & 6 Women & 5 Men and 1 woman & 4 members \\
\hline
\end{tabular}


Table 2. Objectives and Goals of the Projects

\begin{tabular}{|c|c|c|c|}
\hline \multirow[b]{2}{*}{ Stage } & \multicolumn{3}{|l|}{ Project } \\
\hline & $\begin{array}{l}\text { Strawberries } \\
\text { Derivatives }\end{array}$ & \begin{tabular}{|l|} 
Ecological Tourism with \\
Equestrian Tours
\end{tabular} & $\begin{array}{l}\text { Local and Rural Traditional } \\
\text { Gastronomy Tourism }\end{array}$ \\
\hline Objectives & $\begin{array}{l}\text { 1. To apply artisanal } \\
\text { processing strategies } \\
\text { for the managementt } \\
\text { and conservation of } \\
\text { products made of } \\
\text { strawberries. } \\
\text { 2. To improve thet } \\
\text { economic conditions } \\
\text { of rural women tor } \\
\text { survive successfully. } \\
\text { 3. To market products } \\
\text { obtained from the } \\
\text { processing } \\
\text { strawberries in the } \\
\text { community, } \\
\text { educational centers } \\
\text { and regional markets }\end{array}$ & $\begin{array}{l}\text { To promote the ecological } \\
\text { equestrian tourism so that } \\
\text { the peasant families in } \\
\text { Progreso Hidalgo can live } \\
\text { better. } \\
\text { To design a proposal for an } \\
\text { agro-ecological equestrian } \\
\text { tourism, taking advantage } \\
\text { of natural and sociocultural } \\
\text { resources. } \\
\text { To increase the number of } \\
\text { horses for the agro- } \\
\text { ecological tours, in the } \\
\text { community. }\end{array}$ & $\begin{array}{l}\text { 2. To improve the economic } \\
\text { conditions of the inhabitants } \\
\text { of Progreso Hidalgo to } \\
\text { survive successfully in a } \\
\text { globalized world. } \\
\text { 3.To consider the } \\
\text { municipalities of Villa } \\
\text { Guerrero, Zumpahuacán, } \\
\text { Ixtapan de la Sal and } \\
\text { Tonatico, through their tourist } \\
\text { visitors, such as the principal } \\
\text { promoters of the gastronomic } \\
\text { dishes. }\end{array}$ \\
\hline Rationale & $\begin{array}{l}\text { Progreso Hidalgo is a } \\
\text { strawberry-producing } \\
\text { community During } \\
\text { the production process } \\
\text { of this crop, some } \\
\text { commercial risks } \\
\text { appear, like low pricesf } \\
\text { in the market; } \\
\text { environmental ones } \\
\text { such as pests and } \\
\text { diseases, and } \\
\text { meteorological events } \\
\text { (drought, excessive } \\
\text { rains) that influence } \\
\text { the loss of the farming } \\
\text { families. } \\
\text { The management of } \\
\text { strawberries for the } \\
\text { elaboration of jelly, } \\
\text { jams and } \\
\text { crystallization of the } \\
\text { fruit represents an } \\
\text { commercial alternative } \\
\text { to peasant families. }\end{array}$ & $\begin{array}{l}\text { The agro-ecological } \\
\text { equestrian tourism activity } \\
\text { is a potential task for the } \\
\text { community of Progreso } \\
\text { Hidalgo during the entire } \\
\text { year many groups of } \\
\text { families visit it. It is also a } \\
\text { scientific, educational and } \\
\text { academic centre due to its } \\
\text { biological and agricultural } \\
\text { wealth. } \\
\text { The Group Ortiz hase } \\
\text { experience in handling } \\
\text { horses, and they know the c } \\
\text { broad diversity, agro-d } \\
\text { ecological and socio- } \\
\text { cultural importance of the } \\
\text { natural environments of the } \\
\text { community. }\end{array}$ & $\begin{array}{l}\text { Progreso Hidalgo is a village } \\
\text { ythat presents a wide diversity } \\
\text { e of potentialities between them } \\
\text { ofew are environmental, } \\
\text { ebecause of their wide } \\
\text { flandscape, geographic, agro } \\
\text { alecological, sociocultural and } \\
\text { d natural resource variety get an } \\
\text { simpulse to economy, mean by } \\
\text { ll projects that offer a strategy } \\
\text { where the peasant inhabitant } \\
\text { families can get disposable } \\
\text { economic resources for } \\
\text { familiar subsistence. }\end{array}$ \\
\hline
\end{tabular}




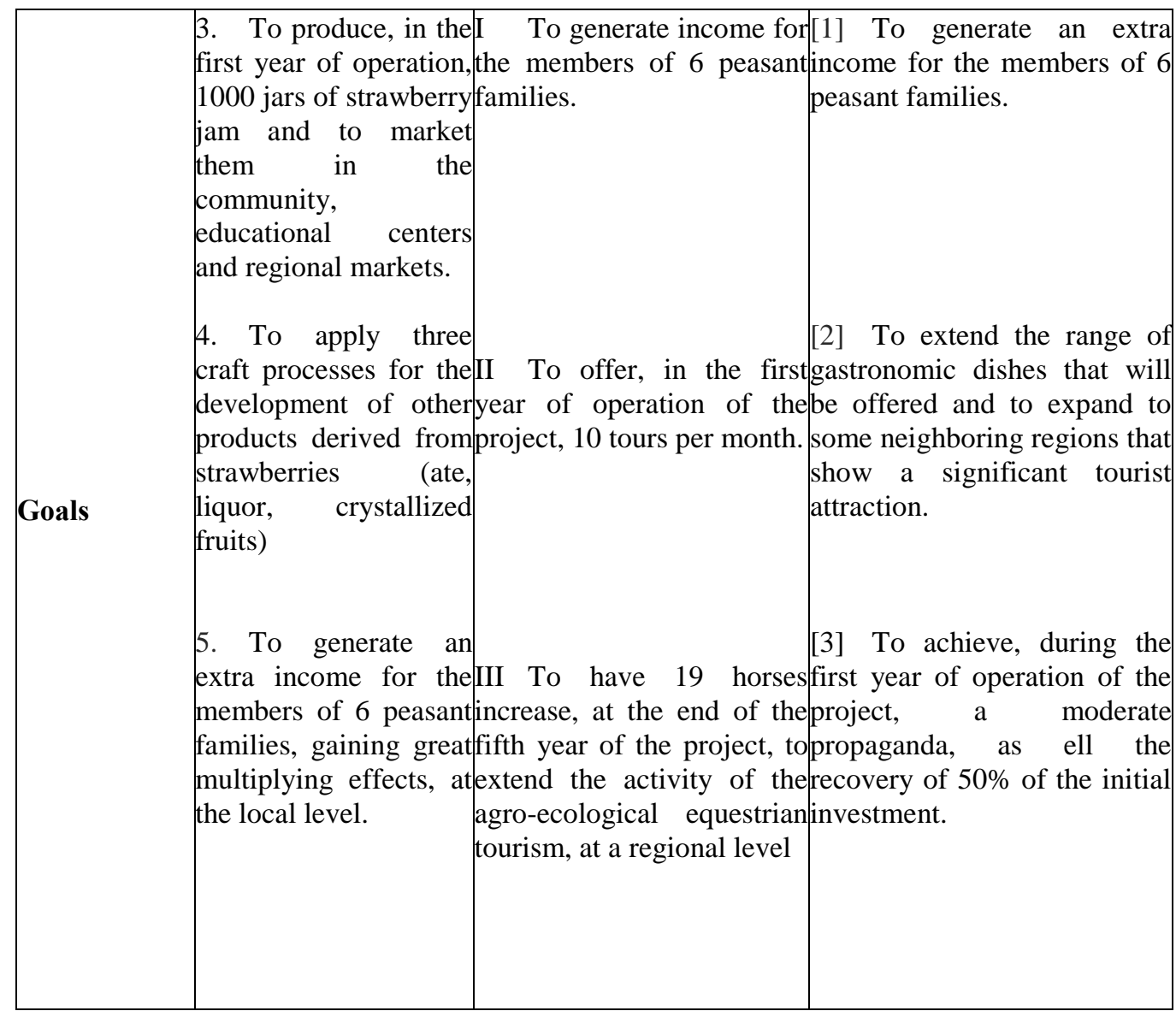

These three projects are designed to contribute to the development of the local community, under the theoretical and methodological approach of SIAL, with a regional vision. The sovereignty and food security of rural families in peripheral rural regions in the State of Mexico is supported. It seeks to generate an extra income for the families, based on the extensive knowledge that the local inhabitants have over their natural resources, from the perspective of Cultural Ecology (Steward, 1972), and the great diversity of uses that they know and practice on their plant resources, from the perspective of ethnobotany (Hernandez, 1976).

Under these approaches, the projects will improve not only the income and the diet of the peasant families, but it will also encourage the ways of generating and transmitting knowledge by reproducing its cultural heritage and strengthening its system of social organization.

Tables 3, 4 and 5 discuss the Market Study of the three projects and include: description and analysis; characteristics of the local market and analysis of supply and demand, as well as the analysis, pricing and marketing strategy. 
Vol. 1, No. $4 \quad$ Gutierrez et al.: Local Rural Gastronomic Traditional Tourism...

Table 3. Market Study: Description and Analysis of Projects

\begin{tabular}{|c|c|c|}
\hline \multirow[b]{2}{*}{ Stage } & \multicolumn{2}{|l|}{ Projects } \\
\hline & 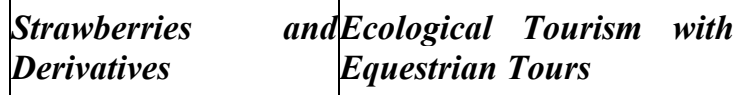 & $\begin{array}{l}\text { Local and Rural Traditional } \\
\text { Gastronomy Tourism }\end{array}$ \\
\hline $\begin{array}{l}\text { Descrip } \\
\text { tion } \\
\text { and } \\
\text { analysis }\end{array}$ & 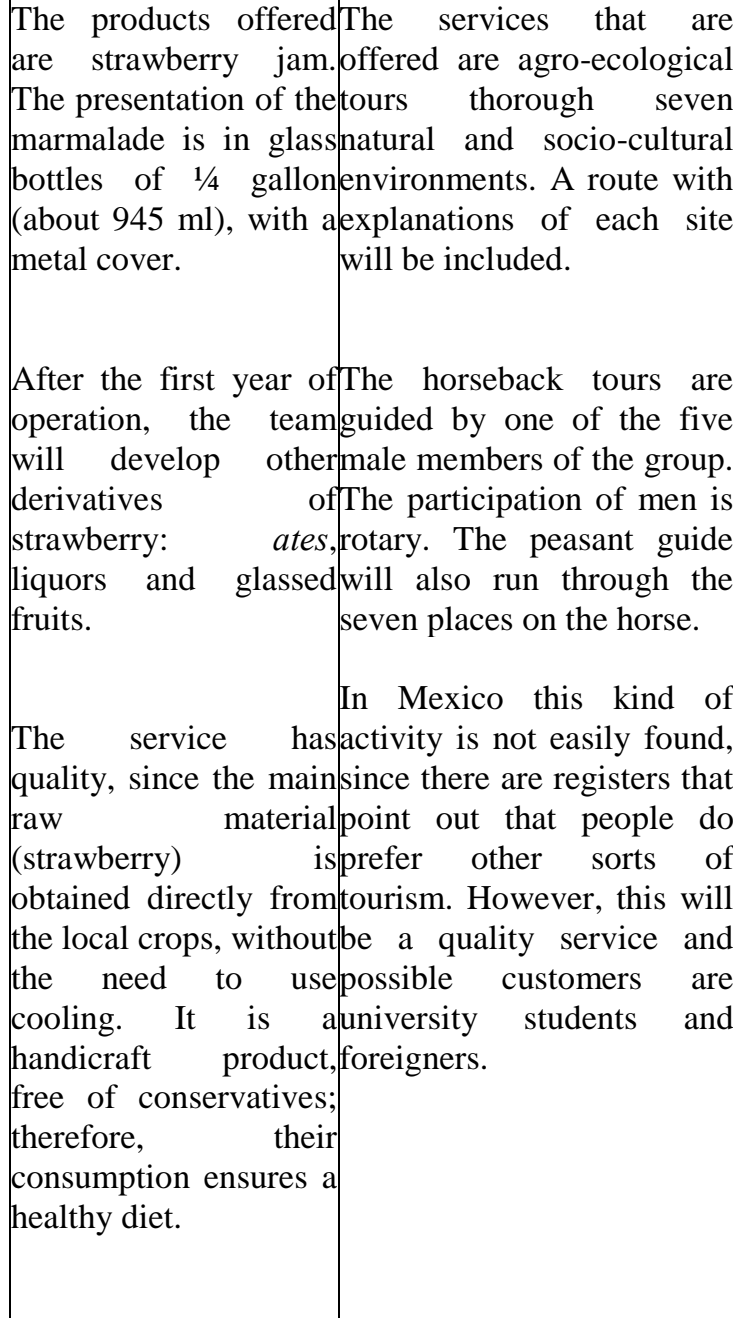 & 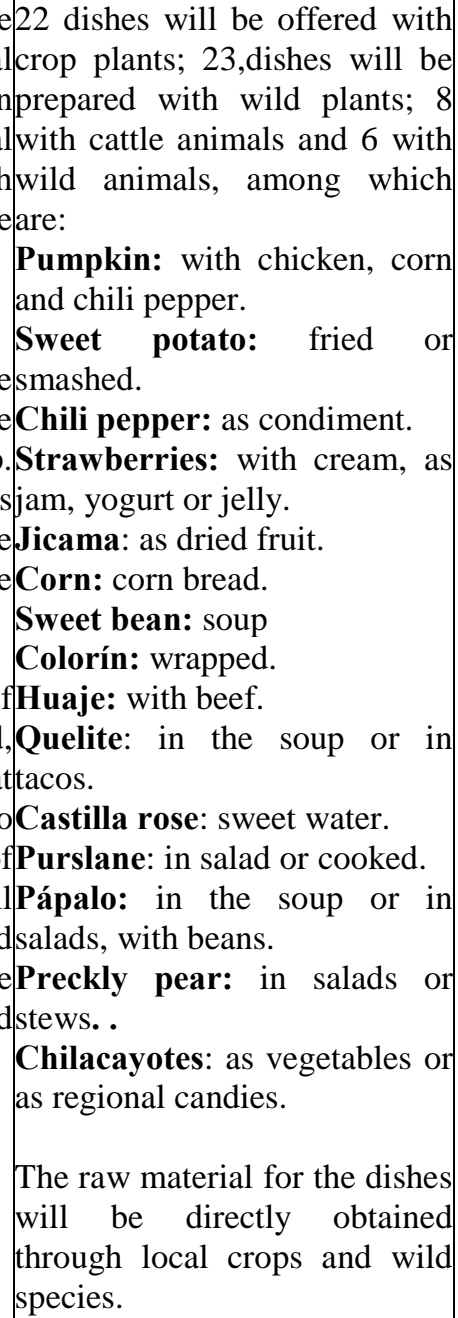 \\
\hline
\end{tabular}


Table 4. Market Study: Characteristics of the Local Market, as well as Supply and Demand Analysis

\begin{tabular}{|c|c|}
\hline Stage & Project \\
\hline & $\begin{array}{c}\text { and Ecological Tourism with } \\
\text { Equestrian Tours }\end{array} \quad \begin{array}{l}\text { Local and Rural } \\
\text { Traditional } \\
\text { Gastronomy Tourism }\end{array}$ \\
\hline $\begin{array}{l}\text { Supp } \\
\text { ly } \\
\text { anal } \\
\text { ysis }\end{array}$ & $\begin{array}{l}\text { Since nobody producesThis kind of service is notThere is not any } \\
\text { the products, there areoffered in the region; the fewProject in the region } \\
\text { not any localones that exist are in Ixtapanthat can offer these } \\
\text { competitors. At regional de la Sal, but there peopleproducts, with a } \\
\text { level, most of theonly watch without listeningspecialized level, } \\
\text { families prepareto any explanations, and thetherefore there are not } \\
\text { strawberry jam, in atour lasts only lasts one hour. local competitors. } \\
\text { small scale, for family } \\
\text { consumption. }\end{array}$ \\
\hline
\end{tabular}

\section{Characteristics of the Local Market}

Based on field work and market diagnosis, the dissemination and commercialization of the product is preferably at a local and regional level. Through distributors, the product comes to educational centers and regional markets. Students, scholars, and researchers in public and private universities, as well as staff of research centers and families from the nearby cities, that are less than 75 miles away, prefer natural foods, free from conservatives.

\section{Demand Analysis}

Progreso Hidalgo is an immigration agricultural center, which represents a great place to market this type of service and product. This town has a high potential for ecological agriculture, for this reason, entire families often immigrate there. During holidays the products will be offered in downtown. The point of sale is the geographical space of the central community, which is encouraged by schemas and patterns of social organization and mutual support, a relevant feature of peasant families.

The community is the center of agricultural work that receives more than 200 people per week, mainly in the months of agricultural production. During religious festivals more than 500 people arrive to the community and are therefore potential customers. 
Vol. 1, No. $4 \quad$ Gutierrez et al.: Local Rural Gastronomic Traditional Tourism...

Table 5. Market Study; Analysis, Price Setting and Marketing Strategy

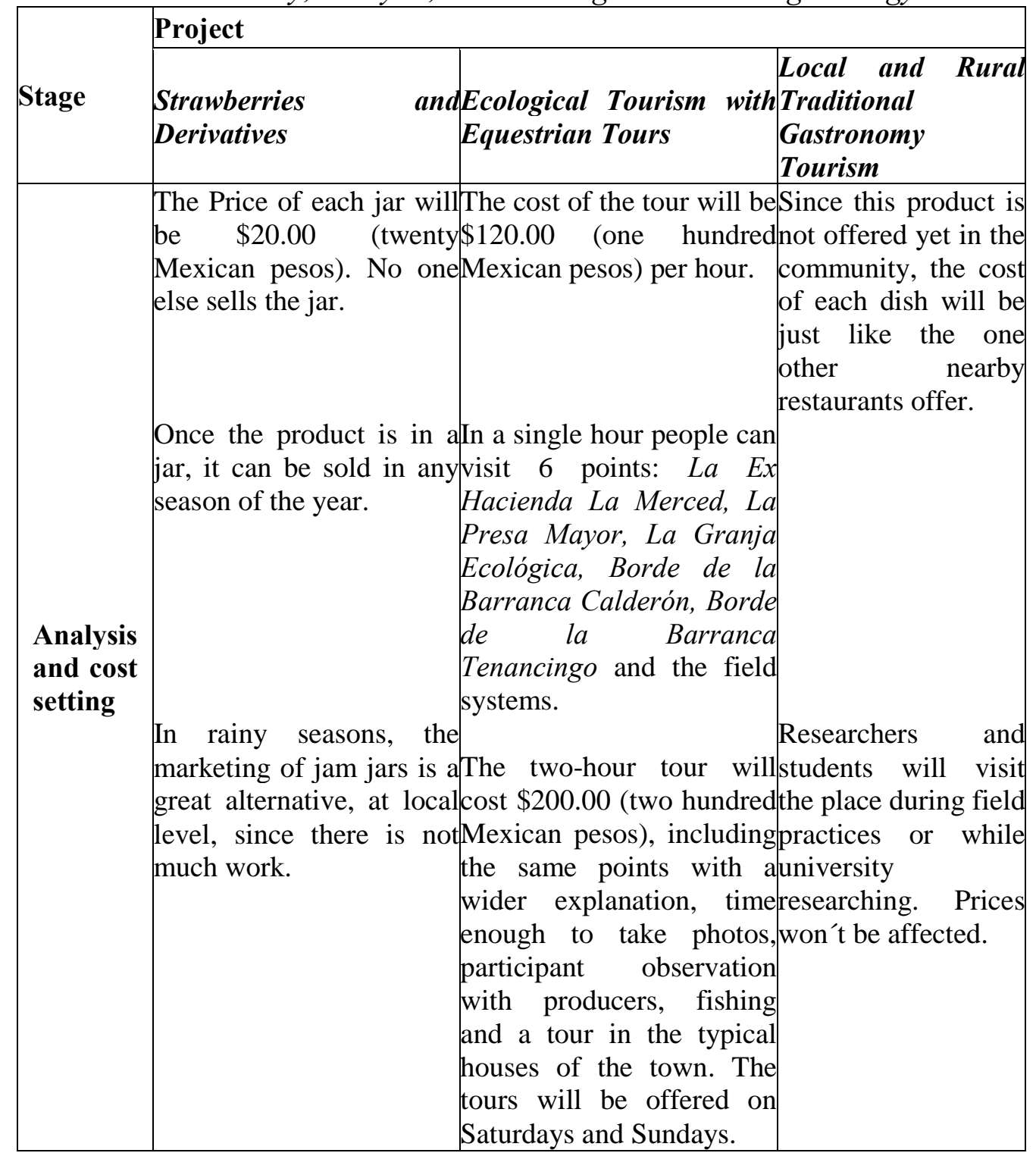

\section{Marketing Strategy}

The promotion and dissemination of products and services is done by establishing channels of communication between the peasant families, students, scholars, and university researchers. The product is sold in cash and on. Because of the particular behavior of the community, products and services are known in meetings and at the end of mass.

Tables 6, 7, 8, 9 and 10 show the various aspects of the Project Engineering, such as the chain of distribution and location of the three projects; the description, infrastructure, requirements and characteristics of the projects; including conditioning of spaces, the installation of the products, the workmanship and contribution of the partners. The production process and marketing of the three projects are also mentioned, as well as the supply of 
products, the attention of customers, the management and maintenance of the processes.

Table 6. Project Engineering: Location

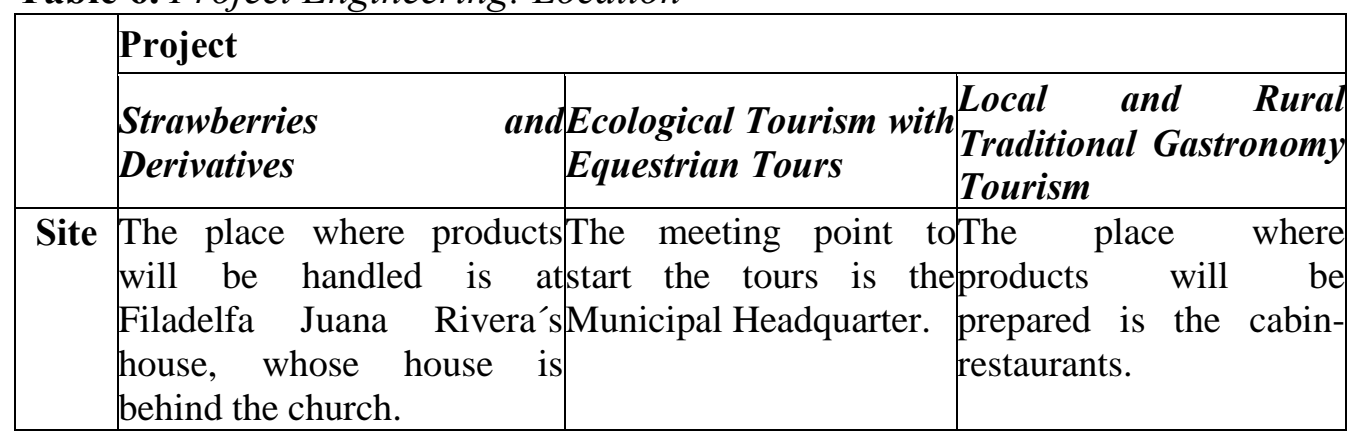

Table 7. Project Engineering: Infrastructure for Projects

\begin{tabular}{|c|c|c|}
\hline \multirow[b]{2}{*}{ Stage } & \multicolumn{2}{|l|}{ Project } \\
\hline & $\begin{array}{l}\text { Strawberries } \\
\text { Derivatives }\end{array}$ & 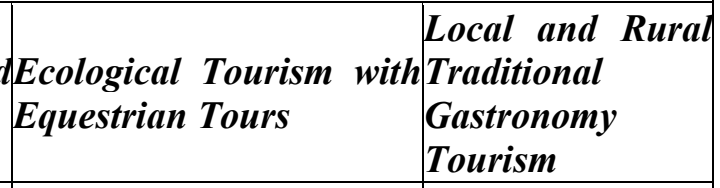 \\
\hline Infrastructure & $\begin{array}{l}\text { Considering the } \\
\text { kitchen and the patio, } \\
\text { the area has } 40 \mathrm{~m}^{2} \\
\text { Raw materials like } \\
\text { sugar, jars, spoons and } \\
\text { casseroles will be kept } \\
\text { there. } \\
\text { For the } \\
\text { implementation of the } \\
\text { project some } \\
\text { improvements in this } \\
\text { location were done. }\end{array}$ & $\begin{array}{l}\text { The land is around To start the } \\
500 \mathrm{~m}^{2} \text { long. There are fiveproject it was } \\
\text { stables of horses. } \\
\text { necessary to build } \\
\text { four we walls were built uprestaurants with a } \\
\text { tin each stable, which havekitchen, } \\
\text { drinking troughs andcupboard, } \\
\text { feeding troughs. There is bathrooms, } \\
\text { an iron sheet as the roof. water tank and a } \\
\text { patio. }\end{array}$ \\
\hline
\end{tabular}


Vol. 1, No. $4 \quad$ Gutierrez et al.: Local Rural Gastronomic Traditional Tourism...

Table 8. Project Engineering: Description of the Projects

\begin{tabular}{|c|c|c|c|}
\hline \multirow[b]{2}{*}{ Stage } & \multicolumn{3}{|l|}{ Project } \\
\hline & $\begin{array}{l}\text { Strawberries } \\
\text { Derivatives }\end{array}$ & $\begin{array}{l}\text { Ecological Tourism with } \\
\text { Equestrian Tours }\end{array}$ & $\begin{array}{l}\text { Local and Rural } \\
\text { Traditional Gastronomy } \\
\text { Tourism }\end{array}$ \\
\hline $\begin{array}{l}\text { Description } \\
\text { of the } \\
\text { project }\end{array}$ & $\begin{array}{l}\text { The following } \\
\text { services can be } \\
\text { found: } \\
\text { III Drinking } \\
\text { water to prepare } \\
\text { products and } \\
\text { clean the jars. } \\
\text { There is also a } \\
\text { pool of lighter. } \\
\text { water. } \\
\text { IV Electricity } \\
\text { service. } \\
\text { V Drainage service. } \\
\text { VI Mobile } \\
\text { services. } \\
\text { VII Paved } \\
\text { roads. } \\
\text { VIII A kitchen to } \\
\text { prepare products. } \\
\text { There are not } \\
\text { limiting factors. }\end{array}$ & $\begin{array}{l}\text { The project is located in } \\
\text { a place where there are } \\
\text { water channels for the } \\
\text { croplands; therefore } \\
\text { water will always be } \\
\text { available. } \\
\text { Traditionally, farming } \\
\text { families give water to } \\
\text { animals at particular } \\
\text { times. There are twenty } \\
\text { levees so water supply is } \\
\text { enough. Electricity is } 200 \\
\text { meters away. } \\
\text { Manure is used for } \\
\text { agricultural purposes. }\end{array}$ & $\begin{array}{l}\text { There are the following } \\
\text { pervices: } \\
\text { prepare wucts and to } \\
\text { clean the recipients. } \\
\text { Each cabin- } \\
\text { restaurant will have } \\
\text { a pool of lighter } \\
\text { water. } \\
\text { VI Electricity service. } \\
\text { VII Drainage service. } \\
\text { VIII Mobile services. } \\
\text { IX Paved roads. } \\
\text { X A kitchen to } \\
\text { prepare products. }\end{array}$ \\
\hline
\end{tabular}

Table 9. Project Engineering: Development of Projects

\begin{tabular}{|c|c|}
\hline \multirow[b]{2}{*}{ Stage } & Project \\
\hline & \begin{tabular}{c|c|c|} 
and Ecological Tourism with \\
Equestrian Tours
\end{tabular} \\
\hline & Location improvements \\
\hline & $\begin{array}{l}\text { The improvements of the Each animal has its ownIt was considered } \\
\text { sites were done by memberspace, including drinkingsince the beginning } \\
\text { of the team and their sons. troughs and feeding troughs of the construction. }\end{array}$ \\
\hline & Products placement \\
\hline & $\begin{array}{l}\text { All materials were placedService is offered atThe raw materials to } \\
\text { out of risks for the familiesdowntown. One member of prepare food are } \\
\text { and the women whothe project takes fineplaced in the fridge } \\
\text { participate in the project.animals to different sites of and located in the } \\
\text { Products are made by twothe community. } \\
\text { women once a week. }\end{array}$ \\
\hline \multirow{3}{*}{ Development } & Labor work and participation of partners \\
\hline & Labor work will be provided by the inhabitants of the locality. \\
\hline & $\begin{array}{l}\text { The main contribution will be their time, taking turns; the physical space and } \\
\text { tools until the investment shows profits. }\end{array}$ \\
\hline
\end{tabular}


Vol. 1, No. $4 \quad$ Gutierrez et al.: Local Rural Gastronomic Traditional Tourism...

\section{Chain of Distribution}

Strawberries and Derivatives

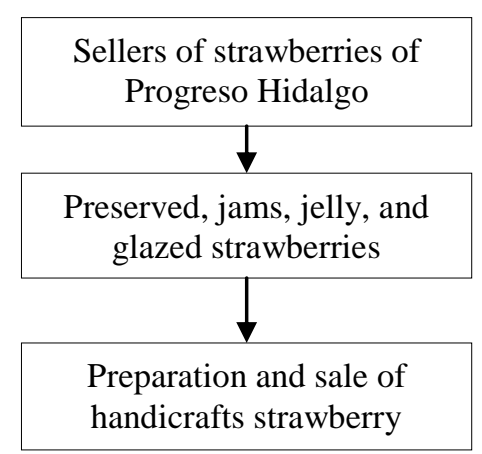

\section{Ecological Tourism with Equestrian Tours}

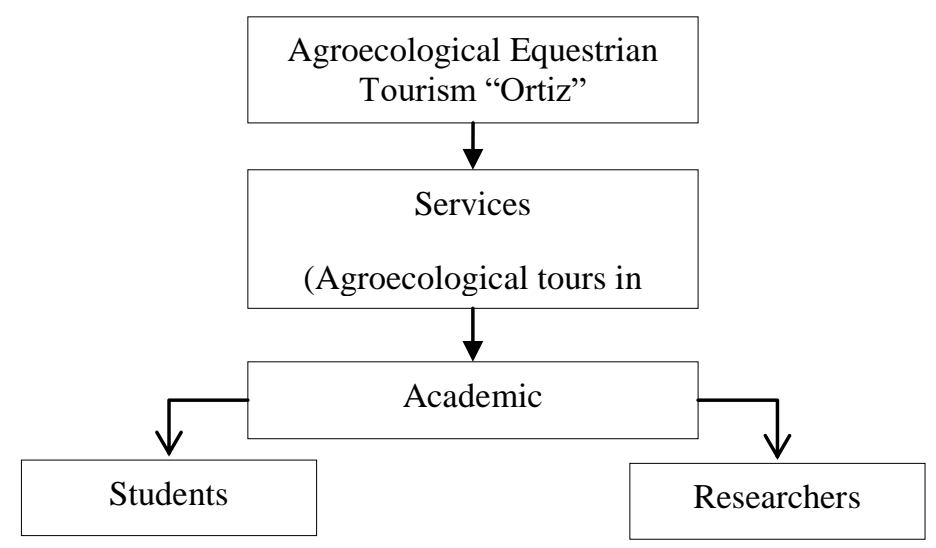

\section{Local and Rural Traditional Gastronomy Tourism}

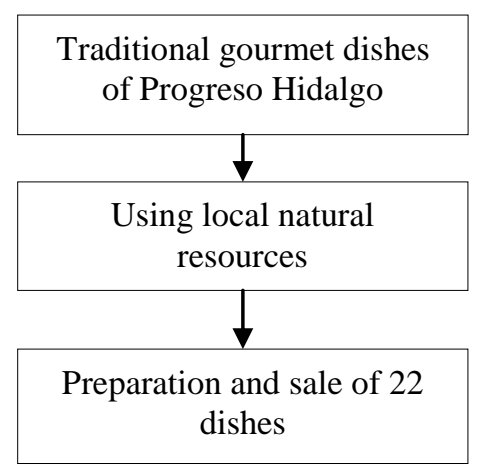


In Tables 11, 12 and 13 aspects related to the impacts and prevention of environment, with corrective and preventive measures based on available technologies and low-cost, which include the management of organic wastes in the three projects, measures for water supply, conservation and proper use of soil, as well as the efficient use of flora, fauna and other resources for the projects are presented.

Table 11. Impact to the Environment: Management of Organic Wastes

\begin{tabular}{|c|c|c|}
\hline \multirow[b]{2}{*}{ Stage } & Project & \\
\hline & 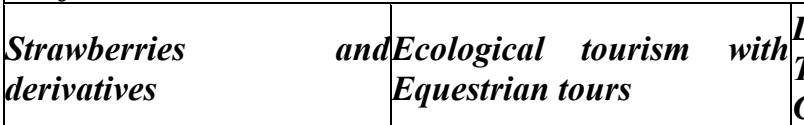 & \begin{tabular}{|l|} 
Local and Rural \\
Traditional \\
Gastronomy tourism
\end{tabular} \\
\hline $\begin{array}{l}\text { Management } \\
\text { of organic } \\
\text { wastes }\end{array}$ & $\begin{array}{l}\text { Organic wastes will be The stools will be used inT } \\
\text { used in strawberry crops, composting to improve soil } \\
\text { and they will be inside 20-in croplands. } \\
\text { liter jars, with a cover, and } \\
\text { then will be spread in To mitigate odor of stool } \\
\text { croplands. } \\
\text { horses there will be } \\
\text { aromatic plants. } \\
\text { During the tours, the guide } \\
\text { will have a special shovel to } \\
\text { pick up wastes and will } \\
\text { send them to croplands. }\end{array}$ & $\begin{array}{l}\text { The organic wastes } \\
\text { will be placed in } \\
\text { recipients for their } \\
\text { final location: } \\
\text { croplands. }\end{array}$ \\
\hline
\end{tabular}

Table 12. Impact to the Environment: Water Supply, Conservation and Proper Use of Soil for the Three Projects

\begin{tabular}{|c|c|c|}
\hline \multirow[b]{2}{*}{ Stage } & \multicolumn{2}{|l|}{ Project } \\
\hline & $\begin{array}{l}\text { and Ecological tourism with } \\
\text { Equestrian tours }\end{array}$ & $\begin{array}{l}\text { Local and Rural } \\
\text { Traditional } \\
\text { Gastronomy tourism }\end{array}$ \\
\hline $\begin{array}{l}\text { Water } \\
\text { supply }\end{array}$ & $\begin{array}{l}\text { Water supply will be Water supply is through } \\
\text { provided from drinking production and distribution } \\
\text { water. Water supply has nochannels. } \\
\text { cost since it is provided by } \\
\text { a committee. The cost is Water goes through a cannel } \\
\text { associated with repair of and is stored in a well of } \\
\text { leaks and cleaning of } 1100 \text { litters. } \\
\text { supply channels. } \\
\text { There is not water } \\
\text { pollution. }\end{array}$ & $\begin{array}{l}\text { Water supply will be } \\
\text { done for the drinking } \\
\text { water installed in the } \\
\text { cabin-restaurant. }\end{array}$ \\
\hline $\begin{array}{l}\text { Conservative } \\
\text { and proper } \\
\text { soil use }\end{array}$ & $\begin{array}{l}\text { There is not soil affectation Risks to soil are not } \\
\text { because the process to adverse, just temporal. To } \\
\text { prepare food is done inside avoid ground compaction, } \\
\text { a house. } \\
\text { horses go to specific sites. }\end{array}$ & $\begin{array}{l}\text { There is not soil } \\
\text { affectation because } \\
\text { the process to prepare } \\
\text { food is done inside } \\
\text { the kitchen, in the } \\
\text { cabin-restaurant. }\end{array}$ \\
\hline
\end{tabular}


Table 13. Impact on Environment: Advantages of Flora, Fauna and other Resources for the Three Projects

\begin{tabular}{|c|c|c|}
\hline \multirow[b]{2}{*}{ Stage } & \multicolumn{2}{|l|}{ Project } \\
\hline & $\begin{array}{l}\text { and Ecological tourism } \\
\text { with Equestrian tours }\end{array}$ & $\begin{array}{l}\text { Local and Rural } \\
\text { Traditional } \\
\text { Gastronomy tourism }\end{array}$ \\
\hline $\begin{array}{l}\text { Harmful } \\
\text { flora and } \\
\text { fauna }\end{array}$ & $\begin{array}{l}\text { Harmful fauna that might There is not harmful } \\
\text { affect the processes willfauna since facilities } \\
\text { be cockroaches and flies, are located } 700 \text { meters } \\
\text { which can be controlledfar away from human } \\
\text { with biodegradablesettlement. } \\
\text { substances that do not } \\
\text { harm the environment. }\end{array}$ & $\begin{array}{l}\text { Harmful fauna that } \\
\text { s might affect process is } \\
\text { s cockroaches and flies, } \\
\text { which can be } \\
\text { controlled } \\
\text { biodegradable with } \\
\text { substances that do not } \\
\text { harm environment. }\end{array}$ \\
\hline $\begin{array}{l}\text { Efficient } \\
\text { advantage } \\
\text { of flora, } \\
\text { fauna and } \\
\text { other } \\
\text { resources }\end{array}$ & $\begin{array}{l}\text { According to the process In natural and } \\
\text { used while preparing cultivated } \\
\text { strawberry products, environments there are } \\
\text { there is not damage for wild vegetables which } \\
\text { the biological elements are consumed by } \\
\begin{array}{ll}\text { of the community. } & \text { horses, affecting flora and } \\
& \text { fauna of the region. }\end{array}\end{array}$ & $\begin{array}{l}\text { According to the } \\
\text { process used while } \\
\text { epreparing organic } \\
\text { hproducts, there won't } \\
\text { y be damages to the } \\
\text { thiological elements of } \\
\text { dthe community. }\end{array}$ \\
\hline
\end{tabular}

\section{Conclusions}

According to the field analysis and the information gathered through surveys that were applied to the community, as well as the Workshop on Desired Scenarios, it was noted that the conditions are favorable to implement a SIAL, since the physical scope in its relationship with actors of the territory, i.e., the inhabitants of this community, show harmony and do not intervene in conflicts for the proper implementation of a system such as the one proposed.

The products that can be considered to promote this system are enough to supply and use, both by the population itself and in business marketing. Local residents show knowledge about the development and preparation of different foods and various edible products, based on the local vegetation and fauna. A SIAL project has great conditions to be implemented in order to develop economy, to increase employment and quality of life that will benefit the greater part of the local population, showing favorable areas for promoting regional development.

In the framework of the destination, the gastronomy stands out for its importance, because it is part of the culture that it defines; without its gastronomy, the destination is incomplete as a tourism product. The current tourism trends are looking for a more direct relationship with the communities and their customs, so gastronomy is a determining factor. Mexico is a country with an extraordinary gastronomy richness; every state, every region and every 
people of this Republic has an extensive list of unique dishes; the odors and flavors offer different itching, sweetness, thicknesses, temperatures, smells, flavors and colors, which allows people to have a great selection of local dishes and, at the same time, an authentic gastronomic configuration.

\section{References}

Barrera, E. 2006. "Turismo rural: nueva ruralidad y empleo rural no agrícola. Montevideo CINTERFOR/OIT.

Bertoncello, R., 2002. "Turismo y territorio. Otras prácticas, otras miradas”. Aportes y transferencias, 6(2): 29-50. Mar del Plata, CITUNMDP, Pág. 10.

Blanco, M. 2006. Las rutas alimentarias, una herramienta para valorizar los productos de las agroindustrias rurales. El caso de la ruta del queso Turrialba. Segunda Edición ed. Costa Rica: s.n.

Bringas, A.O., 2006. "El turismo rural", Universidad de Sonora. Hermosillo, Sonora, México. Pág. 42.

Boucher, F. 2003. Los Sistemas Agroalimentarios Localizados. Una opción para fortalecer las agroindustrias rurales en el marco de la globalización.. D.F, México: CIRAD.

Boucher, F., 2006. Una visión territorial de la Agroindustria rural: Los Sistemas Agroalimentarios Localizados (SIAL). Revista Agroalimentaria, Issue 22, p. 9 y 10.

Camacho, H., 2001. El Enfoque del Marco Lógico. Fundación CIDEAL. Madrid, España.

Cuesta, J. G. 1996. El turismo Rural como factor diversificador de rentas en la tradicional economía agraria. Estudios Turísticos, Issue 122, pp. 45-59.

García, E. 1986. Modificaciones al sistema de clasificación climática de Köeppen. Instituto de Geografía. UNAM. México.

Gobierno del Estado de México. 1995. Página Oficial., Secretaría General de Gobierno del Estado de México.

Hernandez, X. 1976. El concepto de Etnobotánica. Simposio de Etnobotánica en México. INAH. México D.F.

IGECEM. 2010. Cartografía vectorial digital enfocada a la actualización de la cartografía catastral.

Monroy, J. Juan, J.I. Carreto, F. \& Balderas, M. A. 2007. Territorio, Agricultura y Ambiente: Enfoques en el siglo XXI. Primera Edición ed. Toluca, Estado de México: s.n.

Muchnik, J., 2004. Territorios y sistemas agroalimentarios locales. Primera edición ed. Colombia: Unibiblos.

Muchnik, J., Sautier, D. 1998. Systèmes agroalimentaires localisés et construction de territoires. Montpellier: CIRAD.

NAFIN- OEA. 1990. Ciclo de vida de los proyectos de inversión. Memoria del Diplomado. México.

Requier-Desjardins, 2002. Multifuncionalidad y Sistemas Agroalimentarios Localizados. Paris: s.n.

Steward, J. 1972. The Concept and Method of Cultural Ecology. En: Julian Steward. Evolution and Ecology. University Illinois Pres.

Toledo, V. 2000. La Paz en Chiapas. Ecología, Luchas Indígenas y Modernidad Alternativa. Quinto Sol. UNAM, México. 
